\title{
Authorship and date of five family-series nomina in Oligochaeta (Annelida): Lumbricidae, Naididae, Enchytraeidae, Tubificidae and Lumbriculidae
}

\author{
Ton van HAAREN*, Patrick Martin** \& Alain Dubois ${ }^{* * *}$ \\ * Eurofins AquaSense, H.J.E. Wenckebachweg 120, 1114 AD Amsterdam-Duivendrecht, Netherlands \\ ="tonvanhaaren@eurofins.com, @ https://orcid.org/0000-0001-5119-1714 \\ ** Royal Belgian Institute of Natural Sciences, Taxonomy and Phylogeny, 29 rue Vautier, B-1000 Brussels, Belgium. \\ ”patrick.martin@naturalsciences.be, ○ https://orcid.org/0000-0002-6033-8412 \\ ***Institut de Systématique, Évolution, Biodiversité (ISYEB), Muséum national d'Histoire naturelle, Sorbonne Université, \\ École Pratique des Hautes Études, Université des Antilles, CNRS, 57 rue Cuvier, CP 30, F-75005 Paris, France. \\ ”adubois@mnhn.fr, ○ https://orcid.org/0000-0002-6463-3435
}

\section{Introduction}

The International Code of Zoological Nomenclature (Anonymous 1999; 'the Code' below) provides Rules for the nomenclature of the 'names of the group family', or family-series nomina (Dubois 2000). These Rules have long been ignored or disregarded by some taxonomists, so that the authorship(s) and date(s) currently attached in the literature and in some taxonomic online databases to some family-series nomina of ANNELIDA OLIGOCHAETA ${ }^{1}$ prove to be wrong according to the Code. For example, the database Taxonomicon <http://taxonomicon.taxonomy.nl/> credits the nomina NAIDIDAE to Ehrenberg (1828), TUBIFICIDAE to Vejdovský (1876), ENCHYTRAEIDAE to Vejdovský (1879) and LUMBRICULIDAE to Vejdovský (1884a). Vejdovský (1884b: 59) also claimed authorship for the nomen LUMBRICIDAE. All of these attributions are incorrect, as will be established below through a chronological survey of the relevant works where these nomina were made available.

\section{Rafinesque (1815)}

Rafinesque (1815: 135) established a subfamily LUMBRICINIA of his family "CHETOPODIA" (unavailable family nomen for not being based on an available generic nomen). This subfamilial nomen was proposed for a taxon including the genus Lumbricus Linnaeus, 1758, considered valid, and therefore provides the valid authorship and date for the family currently known as LUMBRICIDAE (Anonymous 1978). For an unknown reason, Vejdovský $(1884 b: 59,63)$ stated that he was establishing LUMBRICIDAE as a new family name. This is confusing however, because previously published papers (e.g. Johnston, 1865: 57) as well as one of his own papers (Vejdovský, 1876: 200) had already mentioned the nomen LUMBRICIDAE.

\footnotetext{
1 The nomen Oligochaeta is here used in its original sense (Grube 1850), i.e. excluding the Hirudinea.
} 


\section{Ehrenberg $(1828,1831)$}

The family NAIDIDAE, based on the generic nomen Nais Müller, 1774, was originally established as NAIDINA by Ehrenberg $(1828,1831)$ in his Symbolae physicae. Most recent papers (e.g., Erséus \& Gustavsson 2002; Erséus et al. 2005, 2008; Anonymous 2007) mentioned this taxon as NAIDIDAE Ehrenberg, 1828. However, it has been made clear (Bauer 2000) that-although the plates are from Ehrenberg (1828) - the text is from Ehrenberg (1831). If the nomen NAIDINA had appeared in the plates, this nomen would be dated 1828 , but because NAIDINA was only mentioned in the text, this nomen should be credited to Ehrenberg (1831). Michaelsen (1900) was the only author who attributed the above names correctly; subsequent authors, for reasons unknown, have failed to present the nomenclature properly. The family nomen NAIDIDAE has also been attributed to Benham (1890) (Semernoy 2004; Uzunov 2010) and to Udekem (1855) (Moszyńska 1962; Wilcke 1967)—but these statements are also incorrect.

\section{Udekem $(1855,1859)$}

The family-series nomen TUBIFICIDAE has been attributed to Vejdovský (1876) by most recent authors (Erséus \& Gustavsson 2002; Erséus et al. 2005, 2008; Anonymous 2007). This authorship and date were used to consider TUBIFICIDAE as a junior synonym of NAIDIDAE if both taxa are lumped as a single family, and consequently NAIDIDAE Ehrenberg, 1828 and TUBIFICIDAE Vejdovský, 1876 were placed upon the Official List of Family-Group Names in Zoology (Erséus et al. 2005, 2008; Anonymous 2007). As shown above, the author and date of NAIDIDAE are attributed Ehrenberg (1831), but TUBIFICIDAE should certainly not be attributed to Vejdovský (1876).

Throughout history, the nomen TUBIFICIDAE has been credited to either Udekem (1855) (Moszyńska 1962; Wilcke 1967), Eisen (1879) (Semernoy 2004), Beddard (1895) (Naidu 2005), or Vejdovský (1884b) (Michaelsen 1900; Uzunov 2010). Czerniavsky (1881: 324) reported about "TUBIFICIDAE (D’Udekem) Vejd. 1876", suggesting that Vejdovský (1884b:42) had emended the original nomen of Udekem (1855).

To validate the correct authorship and date of this nomen, the papers by $\operatorname{Udekem}(1855,1859,1865)$ are the most relevant: Erséus et al. (2005: 227) submitted Case 3305 to the Commission (resulting in Opinion 2167: Anonymous 2007) — that the family-series nomina proposed by Udekem $(1855,1859)$ were to be regarded as 'vernacular names'.

Udekem (1855: 539) introduced three families of oligochaetes based upon egg shapes and gave them the following French scientific names: the Lombricins, TUBIFEX and ENCHYTRÉES. Several pages later in this same work (Udekem 1855: 548) he recognised a fourth family, NAÏDES, using the characters of adults. These four families were clearly stated to include, respectively, the genera Lumbricus Linnaeus, 1758, Tubifex Lamarck, 1816, Enchytraeus Henle, 1837 (as Enchytreus) and Nais Müller, 1774 on which they were based and which were used as valid.

Later, Udekem (1859: 4) again used the former three family-series nomina but changed their spellings: "Les Agemmes sont divisées en trois familles que j'avais désignées sous le nom de Lombricins, de Tubifex et d'Enchytréus, noms que je propose de changer en ceux de Lombricidées, Tubifécidées et Enchytridées" ["The 'Agemmes' are divided into three families that I had designated under the name of Lombricins, of Tubifex and of Enchytréus, names which I propose to change into those of Lombricidées, Tubifécidées and Enchytricidées"]. In this work, on pages 8, 9 and 14 he mentioned again these three family nomina, and on page 17 he introduced the new spelling NÄ̈CIDÉES for the fourth family above. Having been expressly presented as intentional, modified spellings of the original nomina, they qualify as emendations of the latter as defined in Article 33.2 of the Code. 
Yet again, Udekem (1865: 12) used these four family nomina under the same spellings as in 1859 - but under modified spellings ending in -IDÉS instead of -IDÉES (Udekem 1865: 5, 25).

In order to understand the nomenclatural statuses of these nomina according to the Code, let us consider their compliance with the criteria of Article 11.7.

Articles 11.7.1.1 and 11.7.2. [1] These four nomina (and their eight emendations) were formed from the stems of available generic nomina used as valid in the new family. [2] Although not Latinised, these eight nomina were clearly proposed specifically for use in taxonomic publications and qualify as scientific names, not as 'vernacular' names - a term which designates a name used by the ordinary people in a particular region (Kottelat 2001; Kluge 2010; Dubois 2015; Dubois \& Ohler 2019). However, because these names were subsequently Latinised - and credited to Udekem (1855 or 1859) by at least some authors - they cannot be rejected as unavailable for not being in Latinised form, as established by Article 11.7.2. [3] Seven of these eight nomina are clearly French nouns in the nominative plural. The nomen Tubifex, being identical to the generic nomen Tubifex, might at first sight be considered as not being in the nominative plural, but this would be wrong, because nouns with an -ex ending are invariable in French: they have the same singular and plural endings, a rule that applies among others (e.g., cortex, index, silex) to the French noun tubifex (see $<\mathrm{https}$ ://www. cnrtl.fr/etymologie/tubifex $>$ ). None of these four nomina can therefore be rejected as unavailable for being in the nominative singular.

Article 11.7.1.3. Neither the original nor the modified spellings of these nomina comply with the suffixes required today by Article 29.2 and 32.5.3 of the Code for nomina of taxa at the rank family, but at that time there was no Code requiring this. Their emendations by Udekem (1859), which were clearly intentional, made them 'closer' to the current correct spelling as they introduced the connector $-I D$ before the ending proper. Although this did not make them 'correct' in the sense of Article 32.5.3, they cannot qualify as 'unjustified emendations' as defined in Article 33.2.3, having their own authors and dates. If it were so, hundreds of other ending changes introduced in family nomina in the taxonomic literature before the Code fixed $-I D A E$ as the correct ending for family nomina would thus qualify as new nomina - an interpretation that, to the best of our knowledge, has never been adopted in the scientific literature. The modified spellings should therefore be considered as mere emendations of their original spellings, being neither justified nor unjustified, and thus should retain their original authorship and date (i.e., d'Udekem, 1855).

As we have seen, these original nomina (LOMBRICINS, TUBIFEX, ENCHYTRÉES and NÄ̈DES) were in the nominative plural and are therefore available family-series nomina. Their subsequent emendationsLOMBRICIDÉ(E)S, TUBIFECIDÉ(E)S, ENCHYTRIDÉ(E)S and NÄ̈CIDÉ(E)S - are not distinct nomina and retain their original authorship and date - even after their justified emendations as LUMBRICIDAE, TUBIFICIDAE, ENCHYTRAEIDAE and NAIDIDAE.

Two of these four nomina, although available, are currently invalid. As we have seen, the nomen NAIDIDAE must be credited to Ehrenberg (1831). As for the nomen LOMBRICINS, although expressly established by Udekem (1855) for a taxon including the genus Lumbricus Linnaeus, 1758, it was based on an incorrect stem (presumably borrowed from the French term 'Lombric'), and qualifies as an incorrect original spelling, which would require emendation; regardless, this nomen is invalid, being a junior synonym of LUMBRICINIA Rafinesque, 1815: 135. Only the second and third nomina, TUBIFICIDAE d'Udekem, 1855 and ENCHYTRAEIDAE d'Udekem, 1855, were new in this work and are therefore the valid nomina of any family-series taxa including respectively the genera Tubifex Lamarck, 1816 and Enchytraeus Henle, 1837. 


\section{Claus $(1868,1872)$}

Claus (1868: 169-170) recognised two families in his suborder OLIGochaETa: the LUMBRICINA and the NAIDEA (both already named earlier, as shown above). He also mentioned three additional familial nomina ("Tubificinen, Enchytraeinen und Naidinen") - names that he credited to Udekem and Germanised (not Latinised). Claus did not implement these names as valid in his classification, treating them as invalid synonyms of NAIDEA, although this decision was not clearly stated in his text.

However, he changed his mind in the second edition of his book (Claus 1872). In his order Oligochaetae, he recognised, among others, the families LuMBricidaE (p. 360), TUbifiCIDAE (p. 361), LUMBRICULIDAE (p. 362), ENCHYTRAEIDAE (p. 362) and NAIDEAE (p. 363). As we have seen, the first, second, fourth and fifth of these nomina had already been made available by previous authors, but this is not the case of the third nomen, LUMBRICULIDAE. Claus (1872) provided a diagnosis of this family and mentioned its genus Lumbriculus Grube, 1844 as valid, thus establishing nomenclatural availability to this nomen.

\section{Subsequent works}

Several subsequent authors either claimed to be the authors of some of the five family-series nomina discussed above, or had credited some of these nomina to authors and dates different from those established above. In particular, Vejdovský $(1876,1878,1884 a-b)$ devoted several papers to the classification and nomenclature of oligochaetes, and even claimed to be the author of some of the nomina above. Although Vejdovskýs classification and nomenclature were followed by some authors - such as Czerniavsky (1881), Scudder (1882) and Michaelsen (1900) who credited him with authorship of the nomen LUMBRICULIDAE, or Scudder (1882), Śtolc (1886) and Michaelsen (1900) who did the same with the nomen TUBIFICIDAE - these statements are incorrect, as we have shown above.

\section{Conclusion}

The correct authors and dates of the five family nomina discussed above are: LUMBRICIDAE Rafinesque, 1815; NAIDIDAE Ehrenberg, 1831; ENCHYTRAEIDAE d'Udekem, 18552; TUBIFICIDAE d'Udekem, 1855; and LuMBriCULIDAE Claus, 1872.

\section{Acknowledgements}

We kindly thank Rüdiger Schmelz (A Coruña, Spain) for his advice and guidance on this subject. Suggested improvements came from Christer Erséus (Göteborg, Sweden), Mathilde and Thierry Frétey (Saint-Maugan, France), Tarmo Timm (Rannu, Estonia) and Mark Wetzel (Champaign, USA), and we extend appreciation to them for their assistance.

2 Full name Gérard-Jules-Marie-Ghislain d'Udekem de Guertechin. He published as either Jules, Marie or Marie Jules. As his first names are French, the authorship is d'Udekem (d' in lowercase), but in bibliographic references his publications should be listed as Udekem, [initials] d' (Frétey 2020; T. Frétey, pers. comm., Febr. 10, 2021). 


\section{References}

Anonymous [International Commission on Zoological Nomenclature] (1978) Opinion 1102. Completion of entry on official list of generic names in zoology relating to Lumbricus Linnaeus, 1758 (Annelida, Oligochaeta) (Name no. 213). Bulletin of zoological Nomenclature, 34 (4): 213-217. <https://www.biodiversitylibrary.org/page/12226490>.

Anonymous [International Commission on Zoological Nomenclature] (1999) International code of zoological nomenclature. 'Fourth edition'. London (International Trust for zoological Nomenclature): i-xxix + 1-306.

Anonymous [International Commission on Zoological Nomenclature] (2007) Opinion 2167 (Case 3305). Naididae Ehrenberg, 1828 (Annelida, Clitellata): precedence over Tubificidae Vejdovský, 1876 maintained. Bulletin of zoological Nomenclature, 64: 71-72. <https://www.biodiversitylibrary.org/page/34356073>.

Bauer, A. M. (2000) The Symbolae Physicae and the Herpetology of Hemprich and Ehrenberg's Expedition to Egypt and the Middle East. Newsletter and Bulletin of the ISHBH, 2 (1): 8-16.

Beddard, F.E. (1895). A monograph of the order of Oligochaeta. Oxford (The Clarendon Press): 1-769. <https://doi. org/10.5962/bhl.title.28557>.

Benham, W.B. (1890). An attempt to classify earthworms. Quarterly Journal of microscopical Science, 31: $201-315$.

Claus, C. (1868) Grundzüge der Zoologie zum Gebrauche an Universitäten und höhern Lehranstalten. Leitfaden zur Einführung in das wissenschaftliche Studium der Zoologie. Marburg \& Leipzig (N. G. Elwert'sche UniversitätsBuchshandlung): i-viii + 1-839. <https://doi.org/10.5962/bhl.title.110152>.

Claus, C. (1872) Grundzüge der Zoologie zum Gebrauche an Universitäten und höheren Lehranstalten sowie zum Selbstudium. Zweite vermehrte Auflage. Marburg \& Leipzig (N. G. Elwert'sche Universitäts-Buchshandlung): i-xii + 1-1170. <https://doi.org/10.5962/bhl.title.3783>.

Czerniavsky, V. (1881) Materialia ad zoographiam ponticam comparatam. Fasc. III. Vermes. Bulletin de la Société impériale des Naturalistes de Moscou, '1880', 55 (4): 213-363, 2 pl. <https://www.biodiversitylibrary.org/ page/34420810>.

Dubois, A. (2000) Synonymies and related lists in zoology: general proposals, with examples in herpetology. Dumerilia, 4 (2): 33-98.

Dubois, A. (2015) The Duplostensional Nomenclatural System for higher zoological nomenclature. Dumerilia, 5: 1108.

Dubois, A. \& Ohler, A. (2019) The nomina Anura, Urodela, Ecaudata and Caudata, credited to 'Fischer von Waldheim, 1813', do not exist, with comments on the nomenclature of higher zoological taxa and on the authorships and dates of other amphibian nomina. Bionomina, 14: 1-68. <https://doi.org/10.11646/bionomina.14.1.1>.

Ehrenberg, C. G. (1828, 1831) Symbolae physicae, animalia evertebrata, exclusis insectis. Series prima cum tabularum decade prima. Phytozoa. 1828: [i-lxix], pl. 1-6. 1831: [i-lii]. <https://www.biodiversitylibrary.org/page/48517197>.

Eisen, G. (1879) Preliminary report on genera and species of Tubificidae. Bihang till Kongliga Svenska vetenskapsakademiens Handlingar, 5 (16): 1-26, 1 pl. <https://www.biodiversitylibrary.org/page/14144806>.

Erséus, C. \& L. Gustavsson (2002) A proposal to regard the former family Naididae as a subfamily within Tubificidae (Annelida, Clitellata). Hydrobiologia, 485: 253-256. <https://doi.org/10.1023/A:1021366204441>.

Erséus, C., Gustavsson, L. \& Brinkhurst, R. O. (2005) Tubificidae Vejdovský, 1876 (Annelida, Clitellata): proposed precedence over Naididae Ehrenberg, 1828. Bulletin of zoological Nomenclature, 62 (4): 226-231. < https://www. biodiversitylibrary.org/page/34357682>.

Erséus, C., Wetzel, M. J. \& Gustavsson, L. (2008) ICZN rules-a farewell to Tubificidae (Annelida, Clitellata). Zootaxa, 1744: 66-68. <https://doi.org/10.11646/zootaxa.1744.1.7>.

Frétey, T. (2020) Patronymic particle and bibliographic citation. Bionomina, 19: 57-63. <https://doi.org/10.11646/ bionomina.19.1.2>.

Grube, E. (1844) Über den Lumbricus variegatus Müller's und ihm verwandte Anneliden. Archiv für Naturgeschichte, 10: $198-216$, pl. 7.

Grube, A. E. (1850) Die Familien der Anneliden. Archiv für Naturgeschichte, 16 (1): 249-364.

Henle, F. G. J. (1837) Ueber Enchytraeus, eine neue Anneliden-Gattung. Archiv für Anatomie, Physiologie und wissenschaftliche Medicin: 74-90, pl. 6.

Johnston, G. (1865) A catalogue of the British non-parasitical worms in the collection of the British Museum. London. 1-365, pl. 1-20. < https://www.biodiversitylibrary.org/page/18294969>.

Kluge, N. J. (2010) Circumscriptional names of higher taxa in Hexapoda. Bionomina, 1: 15-55. <https://doi.org/10.11646/ bionomina.1.1.3>.

Kottelat, M. (2001) Nomenclatural status of names of tetraodontiform fishes based on Bibron's unpublished work. Zoosystema, 23: 605-618.

Lamarck, M. le Chevalier de (1816) Histoire naturelle des animaux sans vertèbres, présentant les caractères généraux et particuliers de ces animaux, leur distribution, leurs classes, leurs familles, leurs genres, et la citation des principales espèces qui s'y rapportent. Tome 3. Paris (Verdière): 1-586. <https://doi.org/10.5962/bhl.title.40014>.

Linnaeus, C. (1758) Systema naturae per regna tria naturae, secundum classes, ordines, genera, species, cum characteribus, differentiis, synonymis, locis. Editio decima, reformata. Tomus 1. Holmia (Laurentius Salvius): [i-iv] 
+ 1-824. <https://doi.org/10.5962/bhl.title.542>.

Michaelsen, W. (1900) Vermes. Oligochaeta. Das Tierreich, 10: i-xxix + 1-575.

Moszyńska, M. (1962) Skaposzczety. Oligochaeta. Katalog Fauny Polski, 11 (2): 1-69.

Müller, O. F. (1774) Vermium terrestrium et fluviatilium, seu animalium infusoriorum, helminthicorum, et testaceorum, non marinorum, succincta historia. Vol. Imi, Pars Altera. Havniæ [Copenhagen] \& Lipsiæ [Leipzig], Heineck \& Faber: $1-72+$ [i-viii]. <https://doi.org/10.5962/bhl.title.12733>.

Naidu, K. V. (2005) The fauna of India and the adjacent countries. Aquatic Oligochaeta. Kolkata (Zoological Survey of India): 1-294.

Rafinesque, C. S. (1815) Analyse de la nature ou tableau de l'univers et des corps organisés. Palerme (Jean Barravecchia): 1-124, 1 pl. <https://doi.org/10.5962/bhl.title.106607>.

Scudder, S. H. (1882) Nomenclator Zoologicus. An alphabetical list of all generic names that have been employed by naturalists for recent and fossil animals from the earliest times to the close of the year 1879. Bulletin of the United States national Museum, 19: 1-340. <https://doi.org/10.5962/bhl.title.1143>.

Semernoy, V. P. (2004) Oligochaeta of Lake Baikal. Novosibirsk (Nauka): 1-528.

Štolc, A. (1886) Přehled českých Tubificidů. Sitzungsberichte der königlichen Böhmischen Gesellschaft der Wissenschaften, '1885': 640-647.

Udekem, J., d' (1855) Nouvelle classification des Annélides sétigères abranches. Bulletins de l'Académie royale des Sciences, des Lettres et des Beaux-Arts de Belgique, 22 (2): 533-555, pl. 1. <https://www.biodiversitylibrary.org/ page/15749775>.

Udekem, J., d' (1859) Nouvelle classification des Annélides sétigères abranches. Mémoires de l'Académie royale des Sciences, des Lettres et des Beaux-Arts de Belgique, 31: 1-28. <https:/www.biodiversitylibrary.org/ page/16207586>.

Udekem, M., d' (1865) Mémoire sur les Lombricins. Première partie. Mémoires de l'Académie royale des Sciences, des Lettres et des Beaux-Arts de Belgique, 35: 1-44, pl. 1-4. <https://www.biodiversitylibrary.org/page/59294630>.

Uzunov, Y. (2010) Aquatic Oligochets (Oligochaeta Limicola). Catalogues Faunae Bulgaricae, 7: 1-123.

Vejdovský, F. (1876) Beiträge zur Oligochaetenfauna Böhmens. Sitzungsberichte der königlichen Böhmischen Gesellschaft der Wissenschaften Praha, '1875': 191-201. <https://www.biodiversitylibrary.org/page/36010171>.

Vejdovský, F. (1878) Zur Anatomie und Systematik der Enchytraeiden. Sitzungsberichte der königlichen Böhmischen Gesellschaft der Wissenschaften, '1877' (5): 294-304.

Vejdovský, F. (1879). Beiträge zur vergleichenden Morphologie der Anneliden. I. Monographie der Enchytraeiden. Prag (Verlag von F. Tempsky): 1-62, 14 pl. <https://doi.org/10.5962/bhl.title.46864>.

Vejdovský, F. (1884a) Revisio Oligochaetorum Bohemiae. Sitzungsberichte der königlichen Böhmischen Gesellschaft der Wissenschaften in Prag / Zprávy o Zasedáni Královské České Společnosti Nauk v Praze, '1883': 215-228. <https:// biodiversitylibrary.org/page/47018525>.

Vejdovský, F. (1884b) System und Morphologie der Oligochaeten. Prag (Franz Řivnáč): 1-166 + i-vi, pl. 1-16. <https:// books.google.com/books/about/System_und_Morphologie_der_Oligochaeten.html?id=L0nKnQEACAAJ>.

Wilcke, D. E. (1967) Oligochaeta. In: P. Brohmer, P. Ehrmann, G. Ulmer \& H. Schiemenz (ed.), Die Tierwelt Mitteleuropas, 1 (7a): 1-161, pl. 1-22.

Submitted: 21 February 2021. Accepted: 16 April 2021. Published: 3 June 2021. Corresponding editor: Erna Aescht. 